\title{
Скринінг накопичення біологічно активних речовин в ірисі угорському впродовж вегетаційного періоду
}

\author{
А. В. Кречун ${ }^{1}$, О. О. Михайленко ${ }^{1}$ С. В. Ковальов ${ }^{1}$, Т. Г. Орлова ${ }^{2}$ \\ ${ }^{1}$ Національний фармацевтичний університет, м. Харків, Україна, ${ }^{2}$ Ботанічний сад Харківського національного університету імені В. Н. Каразіна, \\ Україна
}

A - концепція та дизайн дослідження; В - збір даних; C - аналіз та інтерпретація даних; D - написання статті; E - редагування статті; $\mathrm{F}$ - остаточне затвердження статті

Встановлення динаміки накопичення різних груп біологічно активних речовин (БАР) в рослинах має велике значення для отримання якісної сировини.

Мета роботи - встановлення кількісного вмісту груп БАР у сировині іриса угорського (Iris hungarica) протягом вегетаційного періоду, заготовленого в різних регіонах України.

Матеріали та методи. Попередній аналіз виконали за допомогою методу паперової хроматографії. Кількісний вміст основних груп біологічно активних речовин (гідроксикоричних кислот, фрлавоноїдів, ізофлавоноїдів, ксантонів) встановлювали методом спектрофротометрії.

Результати. У досліджуваних зразках встановили кількісний вміст гідроксикоричних кислот $(2,66-7,44$ \%), фрлавоноїдів (2,12$3,04 \%)$, ізофлавоноїдів (1,03-1,79\%), ксантонів (1,24-1,72 \%). Накопичення БАВ відбувається більш інтенсивно в весняний період вегетації іриса угорського, тільки ізофлавоноїди активніше накопичуються восени, що пов'язано з особливостями синтезу і накопичення вторинних метаболітів цієї рослини. Також відзначено, що в надземній частині іриса угорського акумуляція таких груп БАР, як гідроксикоричні кислоти, фрлавоноїди та ксантони відбувається інтенсивніше. У підземних органів порівняно з пагоном спостерігають більший вміст ізофлавоноїдів.

Висновки. Виконали якісний і кількісний аналіз листя та кореневищ іриса угорського, що заготовлені в різні періоди вегетації в кількох регіонах України. За результатами аналізу можна зробити висновок про більш раціональну заготівлю листя іриса угорського в весняний період вегетації, а кореневища (джерело ізофлавоноїдів) - восени, оскільки в цей час вміст БАР у сировині найвищий.

\section{Скрининг накопления биологически активных веществ в ирисе венгерском в течение вегетационного периода}

\section{А. В. Кречун, О. А. Михайленко, С. В. Ковалев, Т. Г. Орлова}

Установление динамики накопления различных групп биологически активных веществ (БАВ) в растениях имеет большое значение для получения качественного сырья.

Цель работы - установление количественного содержания групп БАВ в сырье ириса венгерского (Iris hungarica) в течение вегетационного периода, заготовленного в разных регионах Украины.

Материалы и методы. Предварительный анализ провели с помощью метода бумажной хроматографии. Количественное содержание основных групп биологически активных веществ (гидроксикоричных кислот, фрлавоноидов, изофлавоноидов, ксантонов) устанавливали методом спектрофотометрии.

Результаты. В исследуемых образцах установили количественное содержание гидроксикоричных кислот $(2,66-7,44$ \%), фрлавоноидов (2,12-3,04 \%), изофрлавоноидов (1,03-1,79 \%), ксантонов (1,24-1,72 \%). Накопление БАВ происходит более интенсивно в весенний период вегетации ириса венгерского, только изофлавоноиды более активно накапливаются осенью, что связано с особенностями синтеза и накопления вторичных метаболитов этого растения. Также отмечено, что в надземной части ириса венгерского аккумуляция таких групп БАВ, как гидроксикоричные кислоты, фрлавоноиды и ксантоны происходит интенсивнее. В подземных органах по сравнению с побегом наблюдали большее содержание изофлавоноидов.

Выводы. Проведен качественный и количественный анализ листьев и корневищ ириса венгерского, заготовленных в разные периоды вегетации в нескольких регионах Украины. По результатам анализа можно сделать вывод о более рациональной заготовке листьев ириса венгерского в весенний период вегетации, а корневища (источник изофлавоноидов) - осенью, так как содержание БАВ в сырье в это время выше.

ВІДОМОСТІ

ПРО СТАТТЮ

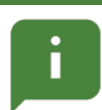

http:l/pharmed.

zsmu.edu.ualarticle/ view/170975
УДК: 615.322:581.43:581.45:582.579.2:577.15/.17:579.222

DOI: 10.14739/2409-2932.2019.2.170975

Актуальні питання фармацевтичної і медичної науки та практики. - 2019. - Т. 12, № 2(30). - С. $135-140$

Ключові слова: ірис, біологічно активні речовини, лікарські трави, кількісне визначення.

*E-mail: ana2017krechun@gmail.com

Надійшла до редакції: 15.03.2019 // Після доопрацювання: 11.04.2019 // Прийнято до друку: 18.04.2019 
Ключевые слова: ирис, биологически активные вещества, лекарственные травы, количественное определение.

Актуальные вопросы фрармацевтической и медицинской науки и практики. - 2019. - Т. 12, № 2(30). - С. 135-140

\section{Screening of accumulation of biologically active substances of Iris hungarica during vegetation period}

\section{A.V. Krechun, O. O. Mikhailenko, S. V. Kovalev, T. H. Orlova}

Establishing of accumulation dynamics of various groups of biologically active substances (BAS) in plants has great importance for obtaining high-quality raw materials.

The aim of the work: to establish the quantitative content of biologically active substances groups in Iris hungarica raw materials during the growing season, harvested in different regions of Ukraine.

Materials and methods. A preliminary analysis was performed using paper chromatography. The quantitative content of the main groups of biologically active substances (hydroxycinnamic acids, flavonoids, isoflavones, xanthones) was determined by spectrophotometry.

Results. The quantitative content of hydroxycinnamic acids (2.66-7.44\%), flavonoids (2.12-3.04 \%), isoflavonoids (1.03-1.79 \%), xanthones (1.24-1.72\%) was established in the studied samples. The accumulation of biologically active substances occurs more intensively during the spring growing season of Iris hungarica, only isoflavonoids accumulate more actively in the autumn, which is associated with the peculiarities of the synthesis and accumulation of secondary metabolites of this plant. It was noted, that in the elevated part of the Iris hungarica, the accumulation of such BAS groups as hydroxycinnamic acids, flavonoids and xanthones occurs more intensively. The highest content of isoflavones is observed in underground organs in comparison with the sprout.

Conclusions. A qualitative and quantitative analysis of leaves and rhizomes of Iris hungarica, harvested in different vegetation periods in several regions of Ukraine, has been carried out. According to the results of the analysis, it is possible to conclude, that harvesting of Iris hungarica leaves is more rational in the spring vegetation period, and the rhizome - as a source of isoflavones - in the autumn, since the content of biologically active substances in the raw material is currently higher.

Key words: iris, biologically active substances, medical plants, biostatistics.

Current issues in pharmacy and medicine: science and practice 2019; 12 (2), 135-140

Встановлення динаміки накопичення різних груп біологічно активних речовин (БАР) у рослинах має велике значення для отримання якісної сировини. Для максимального використання цілющих ресурсів рослин необхідно знати оптимальні строки збирання та заготівлі сировини, щоб вилучити найбільшу кількість БАР. Для кожного виду рослин $є$ індивідуальні терміни заготівлі, що залежать від накопичення певних діючих компонентів (фенольних речовин, алкалоїдів, тритерпенів тощо). Також встановлення динаміки накопичення БАР дасть змогу вивчити біохімічні процеси та роль цих речовин у фізіології рослин.

Рослини родини Iridaceae, рід Iris давно застосовуються в народній та офіційній медицині [1]. Відомо, що сировина ірисів містить флавоноїди, ізофлавоноїди, ксантони, дубильні речовини, гідроксикоричні кислоти [2]. Завдяки різноманітному складу іриси мають широкий спектр біологічної активності: застосовуються для лікування запальних процесів [3], обструкції дихальних шляхів [4], захворювань шлунково-кишкового тракту [5], дерматологічних висипань [6]. Завдяки наявності ксантонового глікозиду мангіферину сировина ірисів також має імуностимулювальну, противірусну, протипухлинну дії [7,8]. Рослини роду Iris є перспективними для наукового вивчення - за останні 10 років виявлено та ідентифіковано понад 90 речовин флавоноїдної природи, серед них 38 - нові сполуки [9].

Iris hungarica Waldst et Kit. (ірис угорський, півники угорські) - багаторічна трав'яниста рослина 15-40 см заввишки, з товстим розгалуженим горизонтальним кореневищем до 2 см завтовшки, від вузлів якого відростають
2-3 переважно одноквіткові гілки. Має пряме лінійно-мечоподібне листя 5-10 мм завширшки, до 45 см завдовжки, часто серпоподібно вигнуте, на кінцях звужене. До зими листя відмирає, навесні з'являється пізніше квітконосів, через це вид має другу назву - безлистий. Тонкий квітконіс, до 50 см заввишки, розгалужений, як правило, не біля основи, а вище середини. Квітки до цвітіння пониклі. Оцвітина яскраво-синьо-фіолетова, зовнішні та внутрішні частини оцвітини майже однакові, обернено яйцевидні. Основа квіток прикрита сильно роздутими, шкірястими листочками обгортки. Оцвітина правильна, з невеликою трубкою та шестироздільним відгином. На зовнішніх злегка загнутих частках розташовані оранжево-жовті «борідки» 3 численних волосків. Плід - циліндрична коробочка. Тригніздна зав'язь - 3 борозенками з боків. Цвіте у другій половині квітня - на початку травня. Плодоносить у липні-серпні. Розмножується насінням і вегетативно. Кріптофіт [10].

\section{Мета роботи}

Встановлення кількісного вмісту груп БАР у сировині іриса угорського протягом вегетаційного періоду, заготовленого в різних регіонах України.

\section{Матеріали і методи дослідження}

Рослинний матеріал. Об'єктами вивчення є листя i кореневище іриса угорського, зібрані навесні (квітень травень) і восени (вересень) в різних місцях зростання на території України (табл. 1). Сировину мили, видаляли відмерлі частини листя та коренів, різали на сегменти 
Таблиця 1. Зразки, які дослідили

\begin{tabular}{|c|c|c|c|}
\hline Зразок & Сировина & Рік заготівлі & Місце заготівлі \\
\hline 1 & листя & \multirow{2}{*}{ квітень 2017} & \multirow{2}{*}{ м. Біла Церква, Державний дендрологічний парк «Олександрія» НАН України } \\
\hline 2 & кореневище & & \\
\hline 3 & листя & \multirow{2}{*}{ квітень 2017} & \multirow{2}{*}{ м. Умань, Національний дендрологічний парк «Софіївка» } \\
\hline 4 & кореневище & & \\
\hline 5 & листя & травень 2017 & \multirow{3}{*}{ м. Київ, Національний ботанічний сад імені М. М. Гришка } \\
\hline 6 & кореневище & вересень 2014 & \\
\hline 7 & кореневище & травень 2017 & \\
\hline 8 & листя & вересень 2017 & \multirow{2}{*}{ м. Харків, ботанічний сад ХНУ імені В.Н.Каразіна } \\
\hline 9 & кореневище & травень 2018 & \\
\hline
\end{tabular}

завдовжки 3-4 см, після чого сушили на повітрі при обмеженому доступі прямих сонячних променів.

Хроматографічний аналіз. Попередньо виконували якісний аналіз сировини ірисів, використовуючи метод паперової хроматографії. Використовували хроматографічний папір марки «Filtrak FN-4», система розчинників БУВ (н-бутанол - оцтова кислота - вода) (4:1:2). Висушену сировину подрібнювали до розмірів 2-3 мм, додавали екстрагент (70 \% етиловий спирт) у співвідношенні 1:10, приєднували зворотний холодильник і нагрівали на водяній бані протягом 1 години. Потім екстракт із листя i кореневища досліджуваних ірисів охолоджували, фільтрували через паперовий складчастий фільтр, концентрували й наносили на лінію старту хроматографічного паперу. Після проходження хроматограму висушували, переглядали у видимому та УФ-світлі.

Кількісний аналіз сировини. Підготовлені зразки подрібнювали та спектрофотометричним методом виконували кількісне визначення груп БАР: гідроксикоричних кислот, флавоноїдів, ізофлавоноїдів, ксантонів. Для встановлення вмісту груп БАР у листі та кореневищі іриса угорського використовували спектрофотометр «Evolution 60S» (США).

Вміст гідроксикоричних кислот встановлювали за загально відомою методикою [11]. Оптичну густину вимірювали при довжині хвилі $327 \pm 2$ нм. Вміст суми гідроксикоричних кислот у сировині ірисів перераховували на хлорогенову кислоту, використовуючи питомий показник поглинання (531).

Для кількісного визначення флавоноїдів застосовували спектрофотометричний метод, в основі якого - реакція комплексоутворення флавоноїдів із хлоридом алюмінію $\left(\mathrm{AlCl}_{3}\right)[12]$.

Кількісний вміст суми ізофлавоноїдів у перерахунку на ононін встановлювали за відомою методикою [13].

Для визначення вмісту ксантонів у листі й кореневищі іриса використовували модифіковану методику [14].

\section{Результати та їх обговорення}

За результатами попереднього дослідження на хроматографічному папері, після проходження та обробки парами аміаку виявлені плями з жовтою, жовто-помаранчевою, синьо-блакитною, блакитно-зеленою, темно-коричневою флуоресценцією, що класифіковані як речовини фенольної природи. Виходячи з цього, виконували кількісний аналіз сировини іриса угорського за основними групами БАР: гідроксикоричні кислоти, ізофлавоноїди, флавоноїди, ксантони, - використовуючи названі методики. Результати кількісного визначення цих груп БАР у досліджуваних зразках наведені в таблиці 2.

За даними, що наведені в таблиці 2, гідроксикоричні кислоти накопичуються приблизно в однаковій кількості в листі й кореневищі, переважно у весняний період заготівлі: середнє значення для листя $-4,7 \%$, для кореневища - 4,6 \%. Однак помічено, що у зразках, які заготовлені в Національному дендропарку «Софіївка», вміст гідроксикоричних кислот набагато більший і становить 7,44 \% у листі, 6,37 \% у кореневищі. Мінімальний вміст гідроксикоричних кислот визначили в листі, яке заготовлене на території дендропарку «Олександрія» - 2,66 \%.

Вміст ізофлавоноїдів у досліджуваних зразках становить від 1,03 \% до 1,79 \%, що відрізняється незначно в листі й кореневищі. Найменшу кількість виявили в листі, яке заготовлене в дендропарку «Олександрія», $1,03 \%$, найбільшу - в кореневищах осінньої заготівлі $(1,79 \%)$.

Середнє значення кількісного вмісту флавоноїдів у листі іриса угорського становить 2,62 \%, в кореневищі 2,60 \%. Встановили: в кореневищі осінньої заготівлі вміст флавоноїдів мінімальний - 1,21 \%, що суттєво відрізняється від вмісту в листі того самого періоду вегетації - 2,95 \%. У листі й кореневищі весняної заготівлі вміст флавоноїдів майже однаковий, варіюється від $2,12 \%$ до $3,04 \%$.

Накопичення ксантонів інтенсивніше відбувається в листі й кореневищі іриса угорського навесні - від 1,34 \% до 1,72\%. Найбільшу кількість зафіксовано в листі, яке заготовлене на території дендропарку «Софіївка».

Отже, накопичення БАР відбувається інтенсивніше у весняний період вегетації іриса угорського, тільки ізофлавоноїди активніше накопичуються восени, що пов'язано з особливостями синтезу й акумуляції вто- 
Таблиця 2. Вміст БАР у сировині іриса угорського, \%

\begin{tabular}{|c|c|c|c|c|c|c|c|c|c|}
\hline \multirow{2}{*}{$\begin{array}{l}\text { Класи } \\
\text { біологічно активних } \\
\text { речовин }\end{array}$} & \multicolumn{9}{|c|}{ Зразки, які дослідили } \\
\hline & 1 & 2 & 3 & 4 & 5 & 6 & 7 & 8 & 9 \\
\hline $\begin{array}{l}\text { Гідроксикоричні } \\
\text { кислоти }^{1}\end{array}$ & $2,66 \pm 0,10$ & $4,41 \pm 0,11$ & $7,44 \pm 0,08$ & $6,37 \pm 0,14$ & $3,92 \pm 0,09$ & $3,43 \pm 0,10$ & $4,19 \pm 0,14$ & $4,81 \pm 0,15$ & $3,15 \pm 0,09$ \\
\hline Ізофлавоноїди² & $1,03 \pm 0,09$ & $1,45 \pm 0,14$ & $1,07 \pm 0,10$ & $1,29 \pm 0,11$ & $1,33 \pm 0,08$ & $1,79 \pm 0,08$ & $1,22 \pm 0,17$ & $1,33 \pm 0,13$ & $1,24 \pm 0,13$ \\
\hline Флавоноїди & $2,60 \pm 0,12$ & $3,04 \pm 0,10$ & $2,12 \pm 0,15$ & $2,73 \pm 0,12$ & $2,82 \pm 0,11$ & $1,21 \pm 0,11$ & $3,02 \pm 0,10$ & $2,95 \pm 0,16$ & $2,95 \pm 0,12$ \\
\hline Ксантони 4 & $1,54 \pm 0,11$ & $1,65 \pm 0,12$ & $1,72 \pm 0,12$ & $1,47 \pm 0,09$ & $1,55 \pm 0,10$ & $1,24 \pm 0,09$ & $1,34 \pm 0,13$ & $1,55 \pm 0,13$ & $1,43 \pm 0,11$ \\
\hline
\end{tabular}

${ }^{1}$ : в перерахунку на хлорогенову кислоту; ${ }^{2}$ : в перерахунку на ононін; ${ }^{3}$ : в перерахунку на рутин; ${ }^{4}$ : в перерахунку на мангіферин.

Таблиця 3. Характеристика кліматичних особливостей ареалу іриса угорського

\begin{tabular}{|c|c|c|c|c|c|c|c|c|}
\hline \multirow[b]{2}{*}{ Місце зростання } & \multicolumn{8}{|c|}{ Кліматичні показники місцевості } \\
\hline & $\begin{array}{l}\text { Геограсфічні } \\
\text { координати }\end{array}$ & $\begin{array}{l}\text { Висота } \\
\text { над рівнем } \\
\text { моря }\end{array}$ & $\begin{array}{l}\text { Середньо- } \\
\text { річна } \\
\text { темпера- } \\
\text { тура, }{ }^{\circ} \mathrm{C}\end{array}$ & $\begin{array}{l}\text { Кількість } \\
\text { опадів/рік, } \\
\text { мм }\end{array}$ & $\begin{array}{l}\text { Відносна } \\
\text { вологість }\end{array}$ & $\begin{array}{l}\text { Тривалість } \\
\text { сонячного } \\
\text { випроміню- } \\
\text { вання, } \\
\text { кВч/m²/день }\end{array}$ & $\begin{array}{l}\text { Період } \\
\text { заморозків, } \\
\text { дні/рік }\end{array}$ & Ґрунт \\
\hline $\begin{array}{l}\text { м. Умань } \\
\text { (Черкаська обл.) }\end{array}$ & $\begin{array}{l}48^{\circ} 44^{\prime} 54^{\prime \prime} \text { п.ш. } \\
\text { 30¹3'18" с.д. }\end{array}$ & $215 \mathrm{~m}$ & $+9,2$ & 551 & 75 & 3,11 & 110 & $\begin{array}{l}\text { чорнозем, } \\
\text { темно-сірий } \\
\text { опідзолений }\end{array}$ \\
\hline $\begin{array}{l}\text { м. Біла Церква } \\
\text { (Київська обл.) }\end{array}$ & $\begin{array}{l}\text { 4948'33" п.ш. } \\
\text { 3006'43" с.д. }\end{array}$ & $178 \mathrm{M}$ & $+8,8$ & 248 & 74 & 3,10 & 97 & $\begin{array}{l}\text { чорнозем, } \\
\text { підзолистий, } \\
\text { дерново-підзолистий, } \\
\text { дерновий, болотний }\end{array}$ \\
\hline $\begin{array}{l}\text { м. Київ } \\
\text { (Київська обл.) }\end{array}$ & $\begin{array}{l}50^{\circ} 27^{\prime} 16^{\prime \prime} \text { п.ш. } \\
\text { 30³1'25" с.д. }\end{array}$ & $187 \mathrm{M}$ & $+9,4$ & 620 & 72 & 3,10 & 69 & $\begin{array}{l}\text { чорнозем, } \\
\text { дерново-підзолистий, } \\
\text { болотний }\end{array}$ \\
\hline $\begin{array}{l}\text { м. Харків } \\
\text { (Харківська обл.) }\end{array}$ & $\begin{array}{l}49^{\circ} 58^{\prime} 50^{\prime \prime} \text { п.ш. } \\
\text { 36¹5'09" с.д. }\end{array}$ & $113 \mathrm{M}$ & $+9,1$ & 532 & 71 & 3,26 & 127 & $\begin{array}{l}\text { чорнозем, } \\
\text { сірий лісовий, } \\
\text { дерново-підзолистий, } \\
\text { рідко - солончак }\end{array}$ \\
\hline
\end{tabular}

ринних метаболітів цієї рослини. Визначили також, що в надземній частині іриса угорського акумуляція таких груп БАР, як гідроксикоричні кислоти, флавоноїди та ксантони відбувається інтенсивніше. У підземних органах порівняно з пагоном виявили більший вміст ізофлавоноїдів. Ці процеси зумовлені тим, що у весняний період кореневища ірисів перебувають у підготовці до інтенсивного зростання та розвитку надземної частини, тому накопичені за період спокою поживні речовини містяться в максимальній кількості. В осінній період вегетації кореневища іриса угорського акумулюють у більшій кількості полісахариди, пектини, білки, лігнін, аскорбінову кислоту тощо. Базарнова Н. Г. і співавт. встановили, що вихід екстрактивних речовин, котрі отримані різними розчинниками, в сировині іриса сибірського весняного збору перевищує осінній [15].

Сировину іриса угорського заготовляли в різних регіонах України, що мають кліматичні особливості та структуру грунтового покриву (табл. 3).

Національний дендрологічний парк «Софіївка» НАН України розташований в м. Умань (Черкаська обл.) у степовій зоні з помірною кількістю опадів (551 мм/рік) і тривалим теплим періодом.
Дендрологічний парк «Олександрія» знаходиться в м. Біла Церква (Київська обл.) із переважним помірно-континентальним кліматом - 3 малою кількістю опадів (248 мм/рік), відносно невисокою середньорічною температурою повітря $\left(+8,8^{\circ} \mathrm{C}\right)$.

Національний ботанічний сад імені М. М. Гришка НАН України розташований в Києві, близький територіально з дендропарком «Олександрія». Особливість київського саду - переважання континентального та морського клімату, що характеризується вищою середньорічною температурою $\left(+9,4^{\circ} \mathrm{C}\right)$ і великою кількістю опадів (620 мм/рік). Днів заморозків у цьому регіоні найменша кількість.

Ботанічний сад Харківського національного університету імені В. Н. Каразіна (м. Харків) розташований також у помірно-континентальному кліматичному поясі, що характеризується невеликою кількістю опадів (532 мм/ рік), великою кількістю сонячного випромінювання та днів із заморозками, що свідчить про спекотне літо й мінливу холодну зиму.

Також виявили, що у зразках, котрі заготовлені на території дендропарку «Софіївка», вміст гідроксикоричних кислот (у листі та кореневищі) і ксантонів 
(у листі) максимальний. Це пов'язано, ймовірно, з особливостями клімату цієї місцевості - м'яка зима та тепле літо, достатнє зволоження, інтенсивність сонячної радіації. Сировина, що заготовлена восени у НБС імені М. М. Гришка та навесні в дендропарку «Олександрія», має доволі високий вміст флавоноїдів у листі й кореневищі. У зразках сировини іриса угорського, які заготовлені на території ботанічного саду імені В. Н. Каразіна, вміст усіх груп БАР - у межах середніх значень.

Отже, можна зробити висновок: на акумуляцію гідроксикоричних кислот і ксантонів в ірисі угорському впливовими факторами довкілля є помірна температура повітря, опади та сонячне випромінювання. На інтенсивніше накопичення флавоноїдів та ізофлавоноїдів впливає ступінь зволоження грунту. Висока температура повітря разом із великою кількістю сонячного випромінювання та недостатнім зволоженням грунту в літній період дещо сповільнює акумуляцію наведених груп БАР. Перебіг вторинного метаболізму в онтогенезі рослини не має загальних закономірностей і залежить від його фізіологічної ролі для рослинного організму, а також від зовнішніх факторів середовища.

\section{Висновки}

1. Виконали попередній якісний аналіз листя, кореневища іриса угорського, які заготовлені в різні періоди вегетації в кількох регіонах України.

2. Встановили кількісний вміст флавоноїдів, ізофлавоноїдів, гідроксикоричних кислот, ксантонів у досліджуваних зразках.

3. За результатами аналізу можна зробити висновок про більш раціональну заготівлю листя іриса угорського в весняний період вегетації, а кореневища (джерело ізофлавоноїдів) - восени, оскільки в цей час вміст БАР у сировині більший.

4. Результати дослідження будуть використані надалі для вивчення біохімічних процесів в ірисах.

\section{Подяка}

Колектив авторів висловлює подяку Н. М. Дойко, канд. біол. наук, ст. науковому співробітнику Державного дендрологічного парку «Олександрія» НАН України; Т. А. Швець, ст. науковому співробітнику Національного дендрологічного парку «Софіївка»; Ю. В. Буйдіну, ст. науковому співробітнику Національного ботанічного саду імені М. М. Гришка за допомогу в роботі.

Конфлікт інтересів: відсутній.

Conflicts of interest: authors have no conflict of interest to declare.

\section{Відомості про авторів:}

Кречун А. В., аспірант каф. фармакогнозії, Національний фрармацевтичний університет, м. Харків, Україна. ORCID ID: 0000-0001-5545-9415

Михайленко О. О., канд. фарм. наук, асистент каф. ботаніки, Національний фармацевтичний університет, м. Харків, Україна. Ковальов С. В., д-р фарм. наук, доцент каф. нутриціології та медичної броматології, Національний фармацевтичний університет, м. Харків, Україна.
Орлова Т. Г., старший науковий співробітник, зав. відділу квітководекоративних рослин, Ботанічний сад Харківського національного університету імені В. Н. Каразіна, Україна.

\section{Сведения об авторах:}

Кречун А. В., аспирант каф. фрармакогнозии, Национальный фармацевтический университет, г. Харьков, Украина.

Михайленко О. А., канд. фрарм. наук, ассистент каф. ботаники, Национальный фрармацевтический университет, г. Харьков, Украина. Ковалев С. В., д-р фарм. наук, доцент каф. нутрициологии и медицинской броматологии, Национальный фармацевтический университет, г. Харьков, Украина.

Орлова Т. Г., старший научный сотрудник, зав. отделом цветочнодекоративных растений, Ботанический сад Харьковского национального университета им. В. Н. Каразина, Украина.

Information about authors:

Krechun A. V., Aspirant of the Pharmacognosy Department, National University of Pharmacy, Kharkiv, Ukraine.

Mykhailenko O. O., PhD, Associate Professor of the Botany Department, National University of Pharmacy, Kharkiv, Ukraine.

Kovalov S. V., Dr.hab., Associate Professor of the Nutritionology and Medical Bromatology Department, National University of Pharmacy, Kharkiv, Ukraine.

Orlova T. H., Senior Researcher, Head of the Department of Flower and Ornamental Plants, Botanical Garden of the V. N. Karazin Kharkiv National University, Ukraine.

\section{Список літератури}

[1] Xu Z., Chang L. Iridaceae. Identification and Control of Common Weeds. 2017. Vol. 3. P. 905-908.

[2] Kaššák P. Screening of the chemical content of several Limniris group Irises. Journal of Pharmacognosy and Phytochemistry. 2014. Vol. 3. Issue 2. C. 11-14.

[3] Phenolic, flavonoid contents, anticholinesterase and antioxidant evaluation of Iris germanica var; florentina / F. Ullah, M. Ayaz, A. Sadiq, A. Hussain, et al. Natural product research. 2016. Vol. 30. Issue 12. P. 1440-1444. doi: 10.1080/14786419.2015.1057585

[4] Mir A. H. Pharmacological and phytochemical properties of Iris kashmiriana baker as a potential medicinal plant of Kashmir Himalaya. Global Journal of Research on Medicinal Plants \& Indigenous Medicine. 2014. Vol. 3. Issue 12. P. 460.

[5] Basgedik B., Ugur A., Sarac N. Antimicrobial, antioxidant, antimutagenic activities, and phenolic compounds of Iris germanica. Industrial Crops and Products. 2014. Vol. 61. - P. 526-530. doi: 10.1016/j.indcrop.2014.07.022

[6] Major secondary metabolites of Iris spp / W. Kukula-Koch, E. Sieniawska, J. Widelski, O. Urjin et al. Phytochemistry reviews. 2015. Vol. 14. Issue 1. - P. 51-80. doi: 10.1007/s11101-013-9333-1

[7] Anti-inflammatory effects of 6'-O-acetyl mangiferin from Iris rossii Baker via NF-kb signal blocking in lipopolysaccharide-stimulated RAW 264.7 cells / J. H. Jang, K. H. Lee, H. K. Jung, M. O. Sim, et al. Chemico - biological interactions. 2016. Vol. 257. P. 54-60. doi: 10.1016/j.cbi.2016.07.029

[8] Isolation of isoflavones from Iris kashmiriana Baker as potential anti proliferative agents targeting NF-kappaB / A. Alam, V. Jaiswal, S. Akhtar, B. S. Jayashree, et al. Phytochemistry. 2017. Vol. 136. P. 70-80. doi: 10.1016/j.phytochem.2017.01.002

[9] Wang H., Cui Y., Zhao C. Flavonoids of the genus Iris (Iridaceae). Mini reviews in medicinal chemistry. 2010. Vol. 10. Issue 7. P. 643-661. doi: 10.2174/138955710791384027

[10] Marinescu V. M., Alexiu V. Iris aphylla L. ssp. hungarica critically endangered taxon in Europa. Current Trends in Natural Sciences. 2013. Vol. 2. Issue 3. P. 96-99.

[11] Державна Фармакопея України. Харків : Держ. п-во «Науково-експертний фармакопейний центр», 2008. 620 с.

[12] Беликов В. В., Шрайбер М. С. Методы анализа фрлавоноидных соединений. Фармация. 1970. Т. 19. №1. С. 66-72.

[13] Державна Фармакопея України. Харків : Держ. п-во «Науково-експертний фармакопейний центр», 2008. 385 с.

[14] Аслануков А. К., Айрапетова А. Ю., Серебряная Ф. К. Идентификация и количественное определение суммы ксантонов в пересчете на мангиферин в траве копеечника кавказского (Hedysarum 
caucasicum Bieb.) Разработка, исследование и маркетине новой фармацевтической продукции : сб. науч. тр. / под ред. М. В. Гаврилина. Пятигорск, 2009. Вып. 64.854 с.

[15] Скрининг химического состава и биологической активности Iris sibirica L. сорт Cambridge / Н. Г. Базарнова, Т. Н. Ильичёва, Л.И. Тихомирова, А. А. Синицина. Химия растительного сырья. 2016. № 3. C. 49-57. doi: https://doi.org/10.14258/jcprm.2016031227

\section{References}

[1] Xu, Z. \& Chang, L. (2017). Iridaceae. In Identification and Control of Common Weeds. Springer, 3, 905-908. doi: https://doi. org/10.1007/978-981-10-5403-7_37

[2] Kaššák, P. (2014). Screening of the chemical content of several Limniris group Irises. Journal of Pharmacognosy and Phytochemistry, 3(2), 11-14.

[3] Ullah, F., Ayaz, M., Sadiq, A., Hussain, A., Ahmad, S., Imran, M., \& Zeb, A. (2016). Phenolic, flavonoid contents, anticholinesterase and antioxidant evaluation of Iris germanica var; florentina. Natural product research, 30(12), 1440-1444. doi: 10.1080/14786419.2015.1057585

[4] Mir, A. H. (2014). Pharmacological and phytochemical properties of Iris kashmiriana baker as a potential medicinal plant of Kashmir Himalaya. Global Journal of Research on Medicinal Plants \& Indigenous Medicine, 3(12), 460.

[5] Basgedik, B., Ugur, A., \& Sarac, N. (2014). Antimicrobial, antioxidant, antimutagenic activities, and phenolic compounds of Iris germanica. Industrial Crops and Products, 61, 526-530. doi: 10.1016/j.indcrop.2014.07.022

[6] Kukula-Koch, W., Sieniawska, E., Widelski, J., Urjin, O., Głowniak, P., \& Skalicka-Woźniak, K. (2015). Major secondary metabolites of Iris spp. Phytochemistry reviews, 14(1), 51-80. doi: 10.1007/s11101013-9333-1

[7] Jang, J. H., Lee, K. H., Jung, H. K., Sim, M. O., Kim, T. M., Woo, K. W., et al. (2016). Anti-inflammatory effects of 6'-O-acetyl mangiferin from Iris rossii Baker via NF-kb signal blocking in lipopolysaccharide-stim- ulated RAW 264.7 cells. Chemico-biological interactions, 257, 54-60. doi: 10.1016/j.cbi.2016.07.029

[8] Alam, A., Jaiswal, V., Akhtar, S., Jayashree, B. S., \& Dhar, K. L. (2017) Isolation of isoflavones from Iris kashmiriana Baker as potential ant proliferative agents targeting NF-kappa B. Phytochemistry, 136, 70-80. doi: 10.1016/j.phytochem.2017.01.002

[9] Wang, H., Cui, Y., \& Zhao, C. (2010). Flavonoids of the genus Iris (Iridaceae). Mini reviews in medicinal chemistry, 10(7), 643-661. doi: 10.2174/138955710791384027

[10] Marinescu, V. M. \& Alexiu, V. (2013). Iris aphylla L. ssp. hungarica critically endangered taxon in Europa. Current Trends in Natural Sciences, 2(3), 96-99.

[11] (2008) Derzhavna Farmakopeia Ukrainy [State Pharmacopoeia of Ukraine, State Enterprise: Scientific and Expert Pharmacopoeial Centre]. Kharkiv. [in Ukrainian].

[12] Belikov, V. V., \& Schreiber, M. S. (1970). Metody analiza flavonoidnykh soedinenij [Methods of analysis of flavonoid compounds]. Farmaciya, 19(1), 66-72. [in Russian].

[13] (2008) Derzhavna Farmakopeia Ukrainy [State Pharmacopoeia of Ukraine, State Enterprise: Scientific and Expert Pharmacopoeial Centre]. Kharkiv. [in Ukrainian].

[14] Aslanukov, A. K., Airapetova, A. Yu., \& Serebryannaya, F. K. (2009) Identifikaciya i kolichestvennoe opredelenie summy ksantonov v pereschete na mangiferin $v$ trave kopeechnika kavkazskogo (Hedysarum caucasicum Bieb.) [Identification and quantitative determination of the amount of xanthones in terms of mangiferin in the herb of Hedysarum caucasicum Bieb.] Razrabotka, issledovanie i marketing novoj farmacevticheskoj produkcii, 64. Pyatigorsk. [in Russian].

[15] Bazarnova, N. G., Il'ichyova, T. N., Tikhomirova, L. I., \& Sinicina, A. A. (2016). Skrining khimicheskogo sostava i biologicheskoj aktivnosti Iris sibirica L. sort Cambridge. [Screening of the chemical composition and biological activity of Iris sibirica L.,Cambridge variety]. Khimiya rastitel'nogo syr'ya, 3, 49-57. [in Russian]. doi: https://doi.org/10.14258/ jcprm.2016031227 